\title{
Change of senior editors
}

\section{Richard Strange ${ }^{1}$}

Published online: 14 April 2017

(C) Springer Science+Business Media Dordrecht and International Society for Plant Pathology 2017

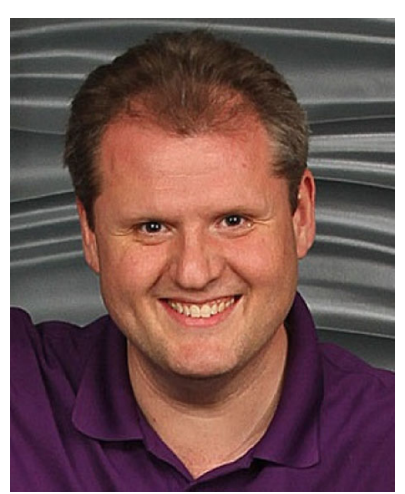

We are sorry to lose Ulrike Grote as Senior Editor in charge of the economics and politics of food security owing to extra government work being placed in her capable hands. However, I believe she may still be available to review the odd paper!
In her place, we are delighted to welcome Derrill D. Watson II. Derrill is an assistant professor of economics specializing in the political economy of food policy, hunger, and the links between climate change and agriculture. He received his $\mathrm{PhD}$ in Economics from Cornell University and his BA in economics from Brigham Young University. Together with Per Pinstrup-Andersen he published a textbook on Food Policy for Developing Countries. He works at Tarleton State University in Texas and has served as a consultant for the World Bank and UNU-WIDER. As a Faculty Fellow of the Center for Instructional Innovation, he regularly assists faculty to develop as teachers and researchers. He has also taught economics in Nigeria and South Africa, English conversation in Germany, and religion courses through the LDS CES system.
Richard Strange

r.strange@ucl.ac.uk

1 University College London, Gower Street, London WC1E 6BT, UK 